\title{
Mechanical Design in Organisms
}





\section{Mechanical Design in Organisms}

S. A. Wainwright

W. D. Biggs

J. D. Currey

J. M. Gosline

Princeton University Press

Princeton, New Jersey 
Published by Princeton University Press, 41 William Street,

Princeton, New Jersey 08540

In the United Kingdom: Princeton University Press,

Chichester, West Sussex

First published 1976

by Edward Arnold (Publishers) Limited, London and by

Halsted Press, a Division of John Wiley \& Sons, Inc., New York

Copyright $\odot 1976$ by S. A. Wainwright, W. D. Biggs,

J. D. Currey, J. M. Gosline

Copyright (C) 1982 by Princeton University Press

\section{ALL RIGHTS RESERVED}

LCC 82-47636

ISBN 0-691-08306-1

ISBN 0-691-08308-8 pbk.

Princeton University Press books are printed on acid-free paper, and meet the guidelines for permanence and durability of the Committee on Production Guidelines for Book Longevity of the Council on Library Resources

Printed in the United States of America by Princeton Academic Press

$\begin{array}{lllll}7 & 6 & 5 & 4 & 3\end{array}$ 